\title{
Long-term air temperature variation in the Karkonosze mountains according to atmospheric circulation
}

\author{
Krzysztof Migala $^{1} \cdot$ Grzegorz Urban $^{2} \cdot$ Karol Tomezyński $^{2}$
}

Received: 19 November 2014 / Accepted: 12 April 2015 / Published online: 27 May 2015

(C) The Author(s) 2015. This article is published with open access at Springerlink.com

\begin{abstract}
The results of meteorological measurements carried out continuously on Mt Śnieżka in Karkonosze mountains since 1880 well document the warming observed on a global scale. Data analysis indicates warming expressed by an increase in the mean annual air temperature of $0.8{ }^{\circ} \mathrm{C} / 100$ years. A much higher temperature increase was recorded in the last two decades at the turn of the twenty-first century. Mean decade air temperatures increased from -0.1 to $1.5^{\circ} \mathrm{C}$. It has been shown that there are relationships between air temperature at $\mathrm{Mt}$ Śnieżka and global mechanisms of atmospheric and oceanic circulation. Thermal conditions of the Karkonosze (Mt Śnieżka) accurately reflect global climate trends and impact of the North Atlantic Oscillation (NAO) index, macrotypes of atmospheric circulation in Europe (GWL) and Atlantic Multidecadal Oscillation (AMO). The increase in air temperature during the 1989-2012 solar magnetic cycle may reveal a synergy effect to which astrophysical effects and atmospheric and oceanic circulation effects contribute, modified by constantly increasing anthropogenic factors.
\end{abstract}

Krzysztof Migała

krzysztof.migala@uni.wroc.pl

Grzegorz Urban

grzegorz.urban@imgw.pl

Karol Tomczyński

karol.tomczynski@imgw.pl

1 University of Wrocław, Institute of Geography and Regional Development, Department of Climatology and Atmosphere Protection, Kosiby St. 1, 51-621 Wrocław, Poland

2 Institute of Meteorology and Water Management-National Research Institute, Wrocław Branch, Parkowa St. 30, 51-616 Wrocław, Poland

\section{Introduction}

In the recent years, in reports on climatology, much attention has been devoted to air temperature trends in the context of global warming, among other things. Studies on the variability of thermal conditions in Poland were mainly carried out on the basis of the longest series of instrumental measurements recorded in Wrocław (Pyka 1998, Bryś and Bryś 2010), Cracow (Trepińska and Kowanetz 1997) and Warsaw (Lorenc 2000). In this line of research, long and homogenous measuring series are very useful. It seems that the most favourable sites to obtain such series are isolated, high-altitude mountain summits not affected by human impact which preserve conditions close to those in a free atmosphere. Conditions in such locations enable us to follow air temperature changes over time with high reliability. All the above characteristics are applicable to the Mount Śnieżka Meteorological Observatory (1603 m a.s.1.) operating since 1 July 1880 . It is one of the key stations in the Global Climate Observing System. It is also part of the Network of European High Mountain Observatories. It is worth to note that there are only a few meteorological observatories in the world with such a long measurement record, located far from direct influence of anthropogenic heat sources (Migała and Czerwiński 2004). The results of meteorological measurements at Mt Śnieżka well document the warming observed on a global scale (Głowicki 1998, 2000, 2003, 2005; Dubicka and Głowicki 2000a, b; Wibig and Głowicki 2002). The latest study including a more than 130year series of measurements addresses the relationship between air temperature and solar activity (Urban and Tomczyński 2015).

The aim of this study was to analyse the variability of air temperature at Mt Śnieżka in the Karkonosze mountains, in a long period from 1881 to 2010 . The relationships between air temperature and frequency of macrotypes of atmospheric 
Fig. 1 Annual mean $\left(T_{\text {avg }}\right)$, mean of maximum $\left(T_{\max }\right)$ and minimum $\left(T_{\min }\right)$ and linear trends of air temperature at Mt Śnieżka in the period 1881-2010

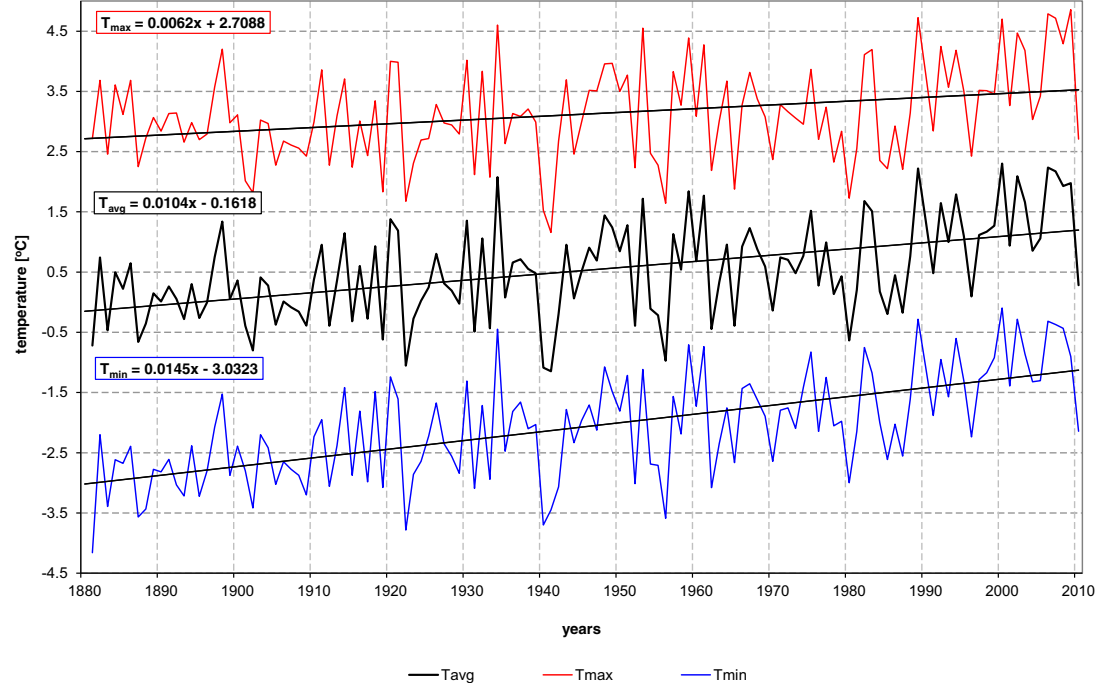

circulation as well as indices of atmospheric (North Atlantic Oscillation - NAO) and oceanic circulation (Atlantic Multidecadal Oscillation - AMO) are investigated. The discussion considers the relationship between air temperature and solar activity.

\section{Study area}

Mt Śnieżka is the highest culmination of the Karkonosze (1603 $\mathrm{m}$ a.s.1.), a range of the Sudetes. It is a highly exposed, not screened summit with geographical coordinates $\varphi \mathrm{N} 50^{\circ}$ $44^{\prime}$ and $\lambda \mathrm{E} 15^{\circ} 44^{\prime}$, situated in the zone of sub-alpine climate, according to the Ellenberg (1978) classification. However, according to Hess (1968), the annual sum of positive air temperatures between 1000 and $1400{ }^{\circ} \mathrm{C}$ classifies this place in the altitudinal belt of very cold climate, below the lower limit of the periglacial zone, determined by an average annual temperature of $-1{ }^{\circ} \mathrm{C}$.

The climate in the Karkonosze is formed under the influence of general processes involving energy and water cycles in a zone of temperate latitude, and it is primarily influenced by Icelandic Low and Azores High atmospheric pressure centres. The local climate character is strongly modified by the influence of altitude and relief. The study area is located
$1000 \mathrm{~km}$ from the Atlantic Ocean and about $350 \mathrm{~km}$ from the Baltic Sea. Due to the geographical location of the Karkonosze mountains in Central Europe, course of the main mountain ridge from WNW to ESE and relatively high absolute altitude, the mountains form a significant orographic barrier for different types of air masses. This is mostly because $64 \%$ of the year the Karkonosze are influenced by humid polar maritime air masses from the North Atlantic, relatively warm during the cold half-year but relatively colder in the warm season (Sobik et al. 2013).

\section{Data and methods}

Source data used in this paper include monthly and annual mean maximum and minimum values of air temperatures recorded at the Śnieżka High Mountain Meteorological Observatory in the 1881-2010 period. The data were retrieved from the archives of Deutscher Wetterdienst (DWD) and the Institute of Meteorology and Water Management-National Research Institute (IMGW-PIB) in Poland. The time series homogeneity of temperature measurements was tested and described by Urban and Tomczyński (2015). Relocation of thermometers and changes of measurement methods did not affect data series homogeneity during a long history of the Observatory.

Table 1 Mean monthly air temperature values $\left(T_{\max }, T_{\text {avg }}\right.$ and $\left.T_{\min }\right)$ and their standard deviations $(\delta)$ at Mt Śnieżka in 1881-2010

\begin{tabular}{lcccccccccccccccc}
\hline Parameter & I & II & III & IV & V & VI & VII & VIII & IX & X & XI & XII & Year \\
\hline$T_{\max }$ & -4.4 & -4.4 & -2.5 & 1.3 & 6.6 & 9.6 & 11.5 & 11.2 & 8.0 & 4.1 & -0.3 & -3.1 & 3.1 \\
$\delta$ & 2.49 & 2.55 & 2.15 & 2.10 & 1.97 & 1.76 & 1.75 & 1.64 & 2.00 & 2.22 & 1.87 & 2.02 & 0.78 \\
$T_{\text {avg }}$ & -7.0 & -7.0 & -5.0 & -1.3 & 3.8 & 6.8 & 8.8 & 8.5 & 5.5 & 1.6 & -2.8 & -5.6 & 0.5 \\
$\delta$ & 2.47 & 2.58 & 2.18 & 2.02 & 1.81 & 1.59 & 1.55 & 1.49 & 1.83 & 2.13 & 1.81 & 2.02 & 0.80 \\
$T_{\min }$ & -9.6 & -9.5 & -7.6 & -3.9 & 1.0 & 4.0 & 6.1 & 5.9 & 3.0 & -0.9 & -5.2 & -8.1 & -2.1 \\
$\delta$ & 2.49 & 2.66 & 2.28 & 2.03 & 1.74 & 1.51 & 1.45 & 1.44 & 1.72 & 2.09 & 1.82 & 2.09 & 0.87 \\
\hline
\end{tabular}


Table 2 Average air temperatures at Mt Śnieżka in the decades of the period 1881-2010

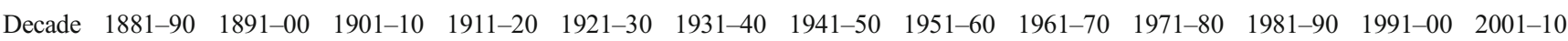

\begin{tabular}{lllllllllllllll}
\hline$T\left[{ }^{\circ} \mathrm{C}\right]$ & 0.0 & 0.3 & -0.1 & 0.4 & 0.3 & 0.4 & 0.5 & 0.5 & 0.6 & 0.5 & 0.8 & 1.2 & 1.5
\end{tabular}

Based on monthly and annual mean maxima and mean minima, monthly mean and annual mean temperatures were calculated as arithmetic means of corresponding mean extremes using the formula $\left(T_{\max }+T_{\min }\right) / 2$. This equation is commonly used to calculate daily air temperatures in North America, Australia and several European countries e.g. Spain and Great Britain (Urban 2010). Consequently, a methodologically homogenous series of monthly and annual mean air temperature values were obtained. The series are free from potential differences resulting from the application of various methods for calculating daily mean values during the analysed period, and consequently free from differences in calculations of monthly and annual mean air temperature values based on measurements taken several to 24 times a day (Lorenc and Suwalska-Bogucka 1995; Urban 2010). Moreover, the adapted calculation method for mean air temperature is reliable for long (e.g. annual) time intervals (Urban 2010, 2013).

The verified time series of air temperatures (monthly mean values with mean maxima and minima) were characterised by descriptive statistics. Among the others, the number of months in temperature categories $(t)$ for $T_{\mathrm{avg}}, T_{\max }$ and $T_{\min }$ at $\mathrm{Mt}$ Śnieżka in 1881-2010 have been described based on the thresholds set by the differences between mean values and their standard deviations $(\sigma)$ : very warm: $t>T+1.5 \sigma$; warm: $T+1.5 \sigma \geq t>T+0.5 \sigma$; normal: $T+0.5 \sigma \geq t \geq T-0.5 \sigma$; cold: $T-$ $0.5 \sigma>t \geq T-1.5 \sigma$; very cold: $t<T-1.5 \sigma$.

A trend for the number of days with mean daily air temperature above $0{ }^{\circ} \mathrm{C}$ was determined. Periodicity of air temperature changes was defined, and its relationship with the mechanisms of atmospheric and oceanic circulation was found.

The dates at which the average temperature exceeded $0{ }^{\circ} \mathrm{C}$ and, consequently, the annual number of days with air temperatures above and below $0{ }^{\circ} \mathrm{C}$ were interpolated on the basis of monthly mean air temperatures, according to a method proposed by Conrad and Pollak (1950).

A cross-correlation function and Fourier analysis of time series, implemented in the Statistica v.10 software package, were used in addition to standard descriptive statistics methods.

Air temperature fluctuations were analysed in a context of air pressure pattern changes over Europe and the northern part of Atlantic Ocean, and two variables were applied: (1) macrotypes of atmospheric circulation and (2) NAO index.
Table 3 Mean air temperature trends $\left[{ }^{\circ} \mathrm{C} / 10\right.$ years] with correlation coefficient $(R)$ for 10 year periods at Mt Śnieżka in 1881-2010

\begin{tabular}{|c|c|c|c|c|c|c|c|c|}
\hline \multirow[t]{2}{*}{ Period } & \multicolumn{2}{|l|}{$T_{\text {avg }}$} & \multicolumn{2}{|l|}{$T_{\max }$} & \multicolumn{2}{|l|}{$T_{\min }$} & \multicolumn{2}{|c|}{$T_{\text {amplitude }}$} \\
\hline & Trend & $R$ & Trend & $R$ & Trend & $R$ & Trend & $R$ \\
\hline Year (I-XII) & 0.104 & 0.90 & 0.062 & 0.69 & 0.145 & 0.96 & -0.083 & 0.88 \\
\hline Warm half-year $(\mathrm{V}-\mathrm{X})$ & 0.102 & 0.78 & 0.055 & 0.46 & 0.149 & 0.92 & -0.094 & 0.86 \\
\hline Cold half-year (XI-IV) & 0.103 & 0.77 & 0.069 & 0.61 & 0.136 & 0.84 & -0.067 & 0.88 \\
\hline Spring (III-V) & 0.111 & 0.78 & 0.064 & 0.52 & 0.158 & 0.87 & -0.094 & 0.78 \\
\hline Summer (VI-VIII) & 0.112 & 0.70 & 0.057 & 0.37 & 0.167 & 0.87 & -0.111 & 0.84 \\
\hline Autumn (IX-XI) & 0.094 & 0.65 & 0.059 & 0.44 & 0.128 & 0.79 & -0.069 & 0.89 \\
\hline Winter (XII-II) & 0.094 & 0.53 & 0.064 & 0.39 & 0.124 & 0.65 & -0.060 & 0.89 \\
\hline January (I) & 0.095 & 0.41 & 0.074 & 0.31 & 0.116 & 0.50 & -0.042 & 0.76 \\
\hline February (II) & 0.087 & 0.41 & 0.049 & 0.24 & 0.126 & 0.55 & -0.076 & 0.80 \\
\hline March (III) & 0.107 & 0.73 & 0.061 & 0.58 & 0.153 & 0.77 & -0.092 & 0.74 \\
\hline April (IV) & 0.134 & 0.60 & 0.088 & 0.41 & 0.181 & 0.73 & -0.093 & 0.76 \\
\hline May (V) & 0.093 & 0.57 & 0.043 & 0.26 & 0.142 & 0.77 & -0.099 & 0.75 \\
\hline June (VI) & 0.089 & 0.53 & 0.030 & 0.17 & 0.148 & 0.77 & -0.118 & 0.83 \\
\hline July (VII) & 0.864 & 0.48 & 0.030 & 0.15 & 0.143 & 0.75 & -0.114 & 0.76 \\
\hline August (VIII) & 0.160 & 0.79 & 0.110 & 0.60 & 0.210 & 0.89 & -0.100 & 0.83 \\
\hline September (IX) & 0.042 & 0.30 & -0.005 & 0.03 & 0.090 & 0.62 & -0.095 & 0.88 \\
\hline October (X) & 0.143 & 0.61 & 0.123 & 0.54 & 0.161 & 0.68 & -0.037 & 0.65 \\
\hline November (XI) & 0.096 & 0.52 & 0.059 & 0.32 & 0.132 & 0.68 & -0.073 & 0.74 \\
\hline December (XII) & 0.101 & 0.49 & 0.074 & 0.39 & 0.128 & 0.57 & -0.054 & 0.75 \\
\hline
\end{tabular}


Fig. 2 Number of months in the classes of temperature $(t)$ for $T_{\text {max }}$ (a), $T_{\text {avg }}$ (b) and $T_{\min }$ (c) at $\mathrm{Mt}$ Snieżka in the period 1881-2010. Explanation: very warm: $t>T+$ 1.5б; warm: $T+1.5 \sigma \geq t>T+0.5 \sigma$; normal: $T+0.5 \sigma \geq t \geq T-0.5 \sigma$; cold: $T-0.5 \sigma>t \geq T-1.5 \sigma$ and very cold: $t<T-1.5 \sigma$. $\sigma$ - standard deviation
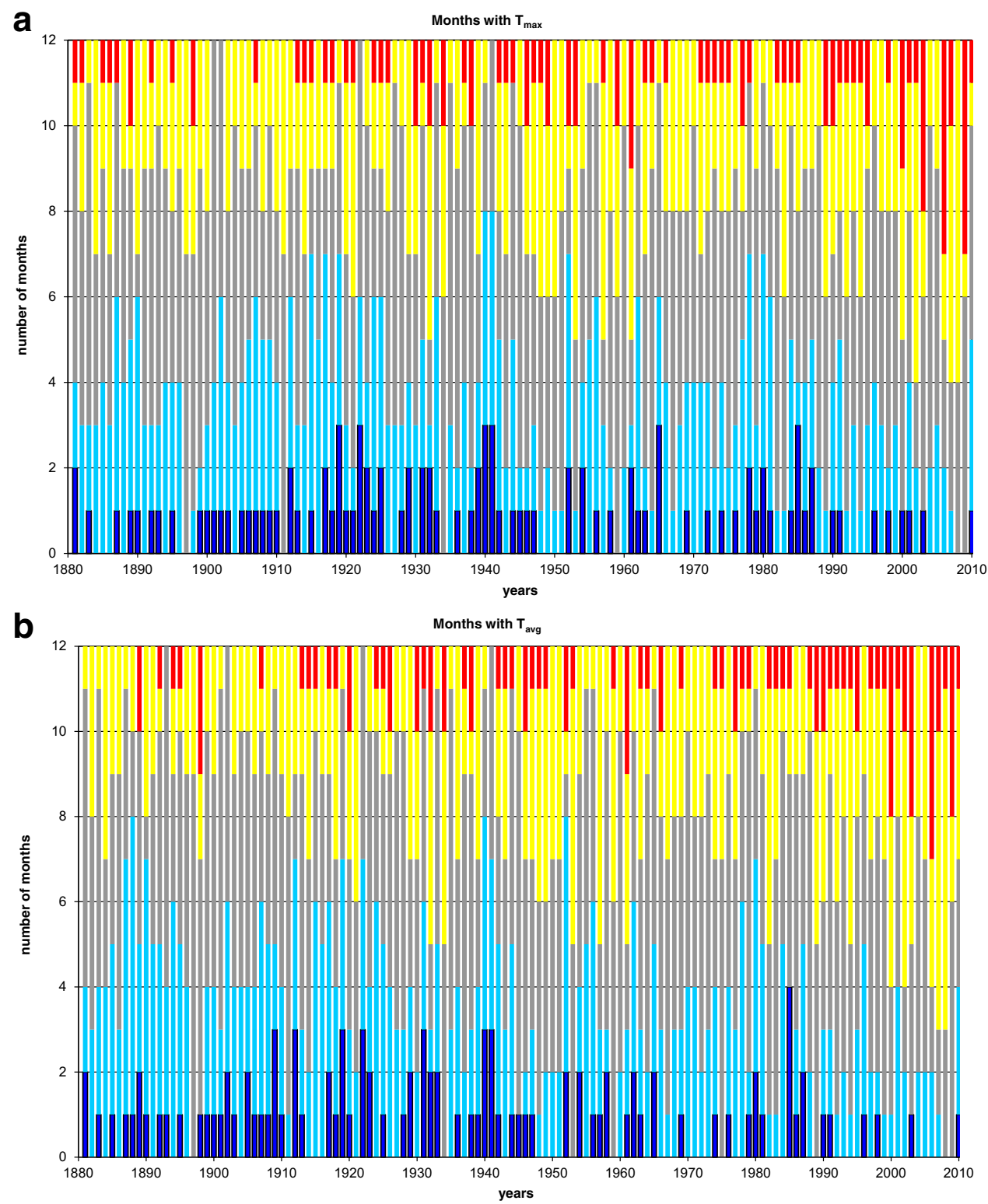

C

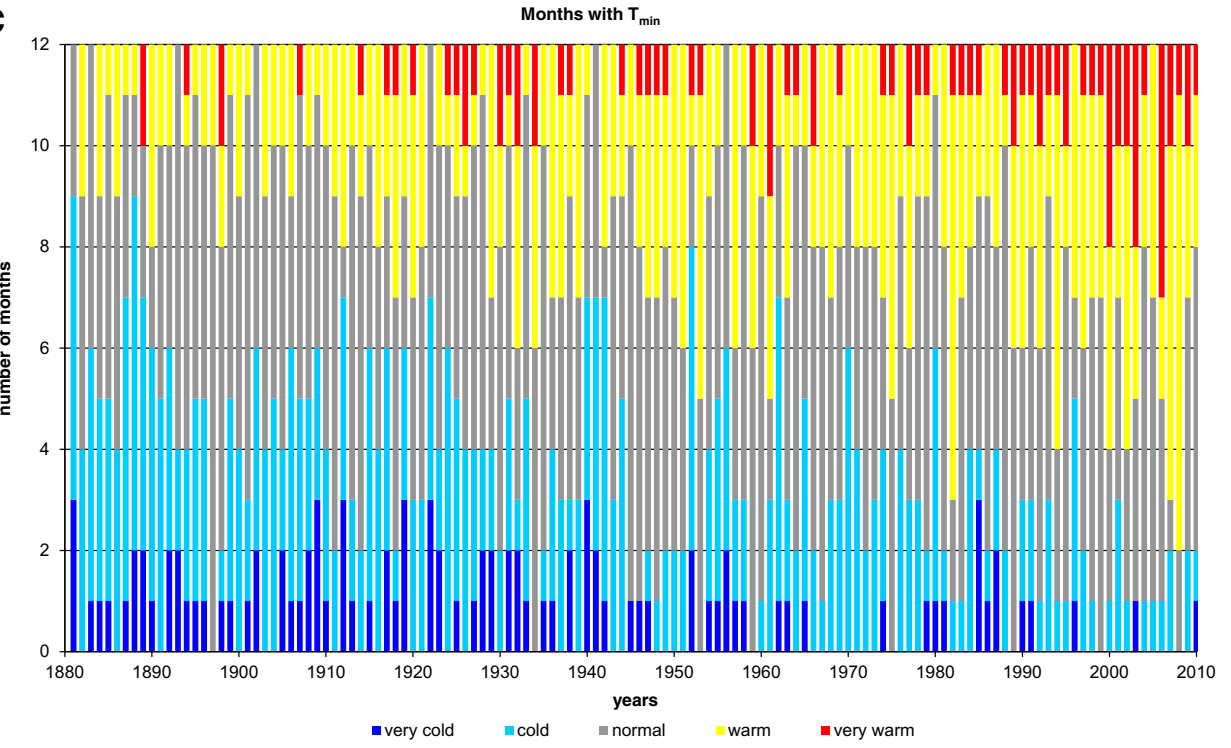


Table 4 Number of very warm (VW) and very cold (VC) months with the temperatures $T_{\text {avg }}, T_{\max }$ and $T_{\min }$ at Mt Śnieżka in respective decades in $1881-2010$

\begin{tabular}{lllllrrrrrrrrrrrr}
\hline Decade & $1881-90$ & $1891-00$ & $1901-10$ & $1911-20$ & $1921-30$ & $1931-40$ & $1941-50$ & $1951-60$ & $1961-70$ & $1971-80$ & $1981-90$ & $1991-00$ & $2001-10$ \\
\hline$T_{\max }$ & VW & 7 & 4 & 1 & 6 & 6 & 8 & 9 & 7 & 6 & 8 & 8 & 10 & 19 \\
& VC & 6 & 5 & 9 & 11 & 12 & 12 & 8 & 6 & 8 & 8 & 9 & 4 & 3 \\
$T_{\text {avg }}$ & VW & 2 & 6 & 1 & 7 & 6 & 8 & 8 & 4 & 8 & 6 & 9 & 13 & 20 \\
& VC & 9 & 6 & 13 & 11 & 9 & 13 & 8 & 8 & 7 & 5 & 9 & 3 & 2 \\
$T_{\min }$ & VW & 2 & 3 & 1 & 4 & 7 & 7 & 5 & 4 & 8 & 6 & 8 & 14 & 20 \\
& VC & 12 & 9 & 13 & 11 & 11 & 12 & 6 & 8 & 3 & 3 & 8 & 2 & 2 \\
\hline
\end{tabular}

Very warm (VW) and very cold (VC) months have been described based on the thresholds set by the differences between mean values and their standard deviations ( $\sigma)$ : very warm: $t>T+1.5 \sigma$; very cold: $t<T-1.5 \sigma$

Changes in air pressure patterns were defined by macrotypes of atmospheric circulation according to a classification of Hess and Brezowsky (1952). Time series data of atmospheric circulation macrotypes (German: Katalog der Grosswetterlagen) were compiled on the basis of a calendar updated by Werner and Gerstengarbe (2010). The NAO index based on the normalised difference of sea level pressure between Lisbon and Reykjavik was defined by Hurrell (1995), and the data were retrieved from Hurrell and National Center for Atmospheric Research Staff (2013). The impact of oceanic water circulation on weather conditions in the Karkonosze mountains was tested on the basis of the Atlantic Multidecadal Oscillation index.

Table 5 Slopes of regression line equations for the number of very warm (VW) and very cold (VC) months according to 10 -year sums at Mt Śnieżka in 1881-2010

\begin{tabular}{lllll}
\hline Parameter & \multicolumn{2}{l}{ VW and $P$ value } & \multicolumn{2}{l}{ VC and $P$ value } \\
\hline$T_{\max }$ & +0.74 & 0.01 & -0.25 & 0.3 \\
$T_{\text {avg }}$ & +0.95 & 0.005 & -0.55 & 0.02 \\
$T_{\min }$ & +1.08 & 0.001 & -0.87 & 0.001 \\
\hline
\end{tabular}

AMO explains the periodicity of sea surface temperature (SST). AMO values smoothed from Kaplan SST V2 (2013) were retrieved from the NOAA/OAR/ESRL PSD website.

\section{Results}

\subsection{Thermal conditions and trends in air temperature at Mt Śnieżka in the period 1881-2010}

The mean annual air temperature at Mt Śnieżka in the entire 130 -year period is $+0.5^{\circ} \mathrm{C}$. The lowest annual mean temperature of $-1.2{ }^{\circ} \mathrm{C}$ was noted in 1941 ; the highest value of + $2.3{ }^{\circ} \mathrm{C}$ was recorded in 2000 and 2006 (Fig. 1). January or February is the coldest with a mean temperature of $-7.0{ }^{\circ} \mathrm{C}$; the warmest is July with a mean monthly air temperature of $8.8^{\circ} \mathrm{C}$.

The most thermally stable month is August, with the lowest standard deviation values $(\delta)$ in every temperature category. February has the highest air temperature variability as evidenced by the high value of standard deviation (Table 1).
Fig. 3 Duration of periods (number of days) with daily mean of air temperature $T>0{ }^{\circ} \mathrm{C}$ and with $T<0{ }^{\circ} \mathrm{C}$ at Mt Śnieżka in the period 1881-2010

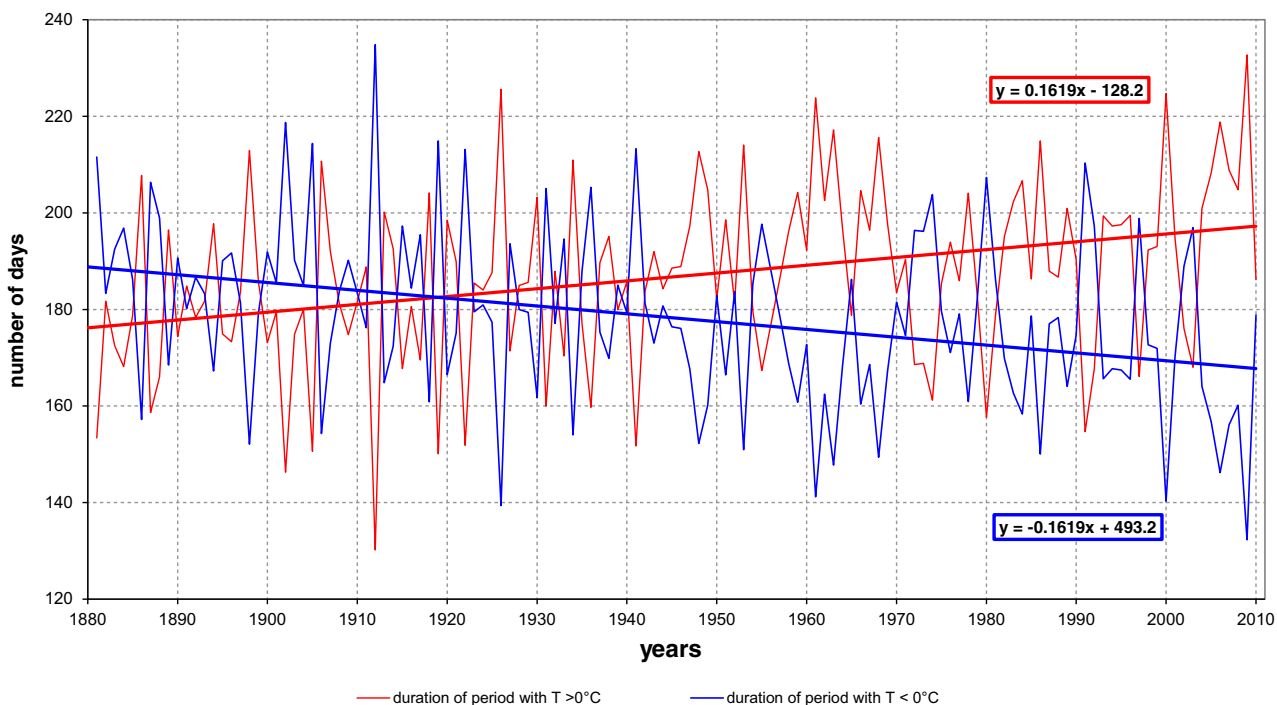


Fig. 4 Annual values of NAO index and mean air temperature $(T)$ at Mt Śnieżka in the years 1881-2010

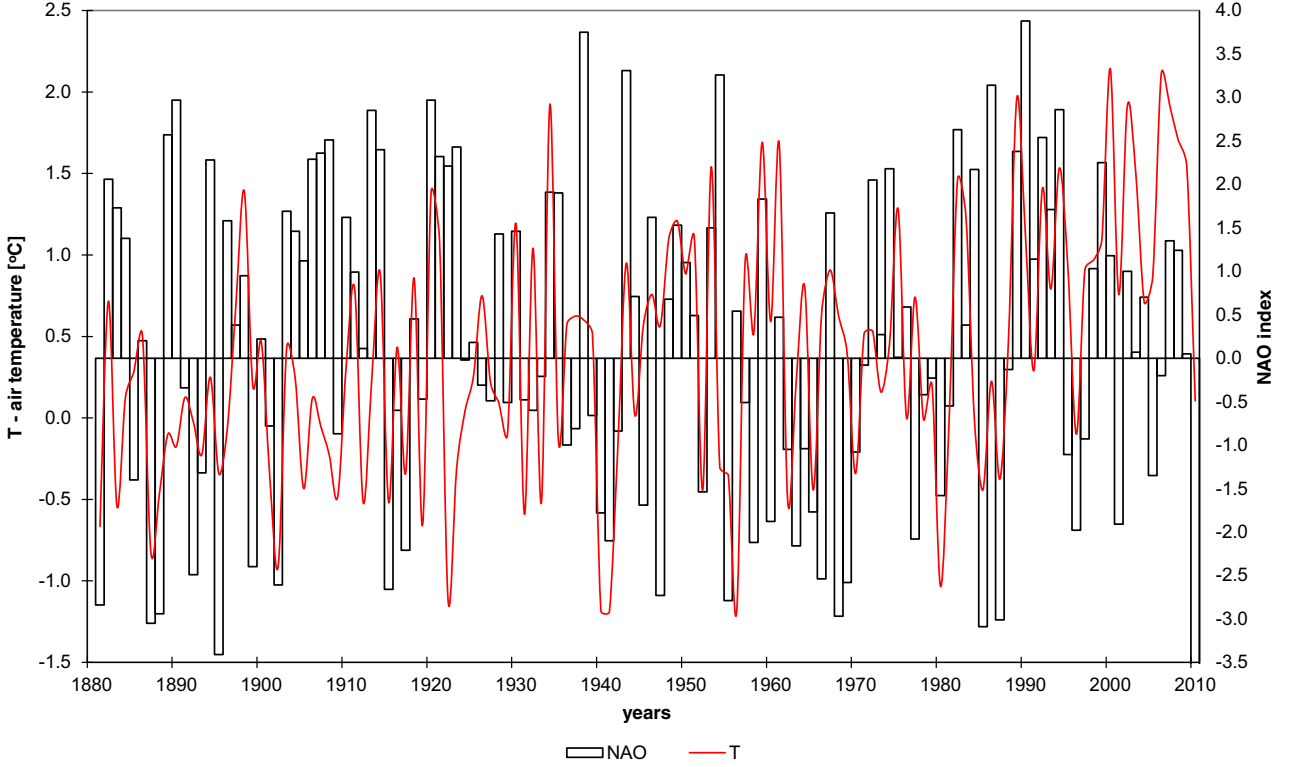

Urban and Tomczyński (2015) indicate that the annual mean temperature trend at Mt Śnieżka in 1881-2010 is $0.104{ }^{\circ} \mathrm{C} / 10$ years. The twice as high increase rate of $T_{\min }$ $\left(0.145^{\circ} \mathrm{C} / 10\right.$ years $)$ than the increase rate of $T_{\max }\left(0.062{ }^{\circ} \mathrm{C} /\right.$ 10 years) determined the observed trend. Consequently, a decreasing trend of the annual mean air temperature amplitude is noted, i.e. $-0.083{ }^{\circ} \mathrm{C} / 10$ years, which indicates a higher oceanic impact and frequency of Atlantic air masses. A number of the authors give similar values of air temperature trends in the Northern Hemisphere in the twentieth century (ObrębskaStarklowa et al. 1994; Schönwiese and Rapp 1997; Auer et al. 2001; Jurkovic et al. 2011; IPCC 2013).

The trends are more pronounced for 10-year periods. The temperature increase is marked in consecutive decades, the last of which (2001-2010) was the warmest with a mean air temperature of $+1.5{ }^{\circ} \mathrm{C}$ (Table 2). Positive trends, with the exception of mid-annual values, are also noticeable for 10year periods (Table 3). The most evident is the twice as higher increase rate of $T_{\min }$ than the increase rate of $T_{\max }$ and decreasing trend of the air temperature amplitudes. Among the seasonal mean values, the highest increase rate occurs for summer and spring $\left(0.112{ }^{\circ} \mathrm{C} / 10\right.$ years and $0.111{ }^{\circ} \mathrm{C} / 10$ years, respectively). The cold season (Nov-Apr) and warm season (May-Oct) have air temperature increase rates almost similar to that of the annual rate, ca. $0.1{ }^{\circ} \mathrm{C} / 10$ years. Higher variability of the air temperature increase rate at Mt Śnieżka in 18812010 is noted for the mean monthly values, from $0.042^{\circ} \mathrm{C} /$ 10 years in September to $0.160^{\circ} \mathrm{C} / 10$ years in August. A high
Fig. 5 Cross-correlation function between annual values of the NAO index and air temperature at Mt Śnieżka for the period 18812010

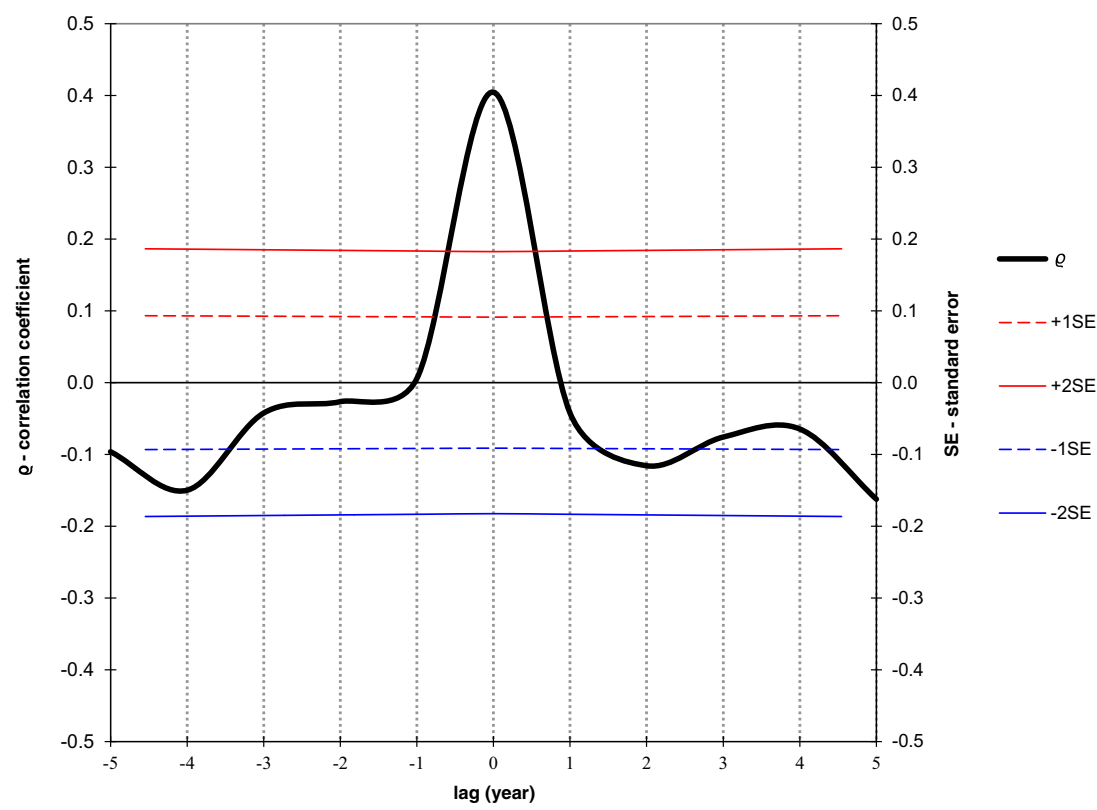


increase rate is also noted for April and October: $0.134{ }^{\circ} \mathrm{C} /$ 10 years and $0.143{ }^{\circ} \mathrm{C} /$ year, respectively (Table 3).

Since the 1970 s, a systematic increase of 10-year air temperature averages from +0.5 to $+1.5{ }^{\circ} \mathrm{C}$ has been seen (Table 2). Furthermore, since the early 1990 s, a marked increase in the frequency of very warm and warm months has been seen, with a reduced number of very cold and cold months. This is noticeable both with respect to average and extreme temperatures, and more significant for monthly $T_{\min }$ averages than for monthly $T_{\max }$ averages (Fig. 2a-c, Tables 4 and 5).

A significant dispersion over respective decades is found, especially in the number of very warm (VW) or very cold (VC) months. It is between 1 (1901-1910) and 19-20 (2001-2010) for VW months in all the temperature categories analysed and between 13 (1901-1910) and 2 (2001-2010) for VC months ( $T_{\text {avg }}$ and $T_{\min }$, Table 4$)$. Most months considered very warm for $T_{\max }, T_{\text {avg }}$ and $T_{\min }$ occurred in the last two decades of the period under study. A particularly high number of very warm months for each temperature category (five) are noted for 2006. The years with the highest frequency (3-4 instances) of very cold months are 1912, 1919, 1922, 1940, 1941, 1965 and 1985.

All the air temperature categories show positive tendencies in very warm months and negative tendencies in very cold months. $T_{\min }$ has the highest increase rates for the number of VW months and the highest decrease rates for the number of VC months according to 10-year sums of +1.08 month/ 10 years and -0.87 month $/ 10$ years, respectively. Furthermore, a much lower (more than 3-fold) rate of decrease in the number of $\mathrm{VC}$ months for $T_{\max }$ than for $T_{\min }$ is noted (Table 5).

This is confirmed by the tendency in dates when average daily air temperatures cross the $0{ }^{\circ} \mathrm{C}$ value. In the $1881-2010$
Fig. 6 Spectral analysis periodogram of mean annual air temperature at Mt Śnieżka (a) and periodogram of NAO index (b) for the years 1881-2010

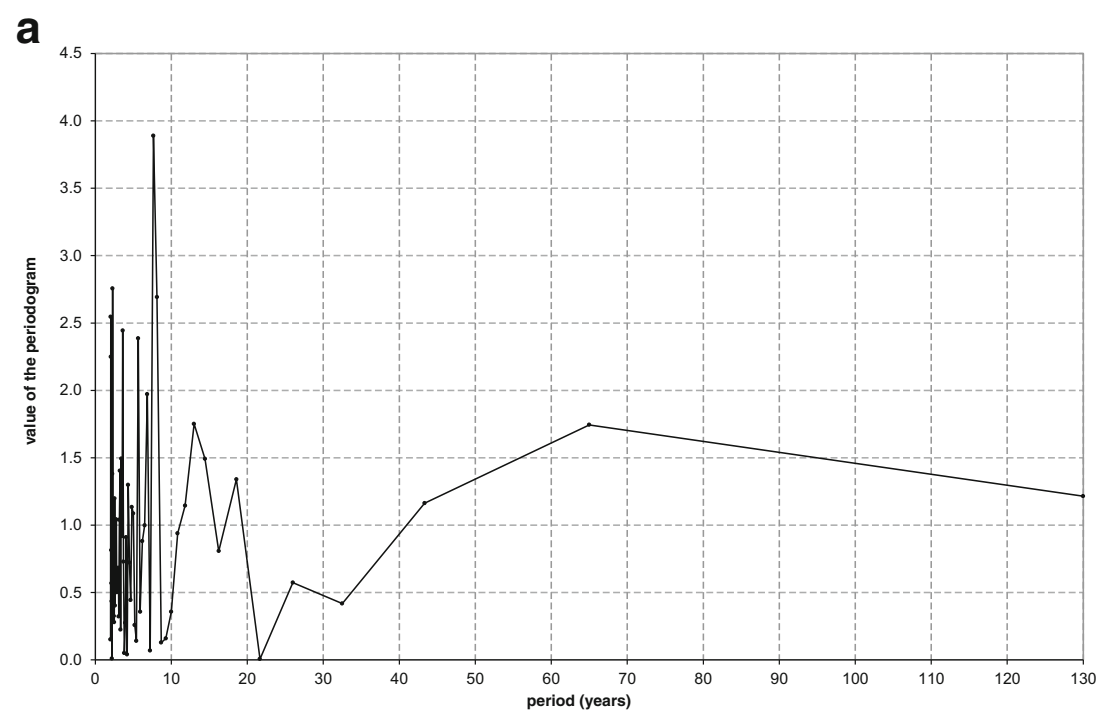

b

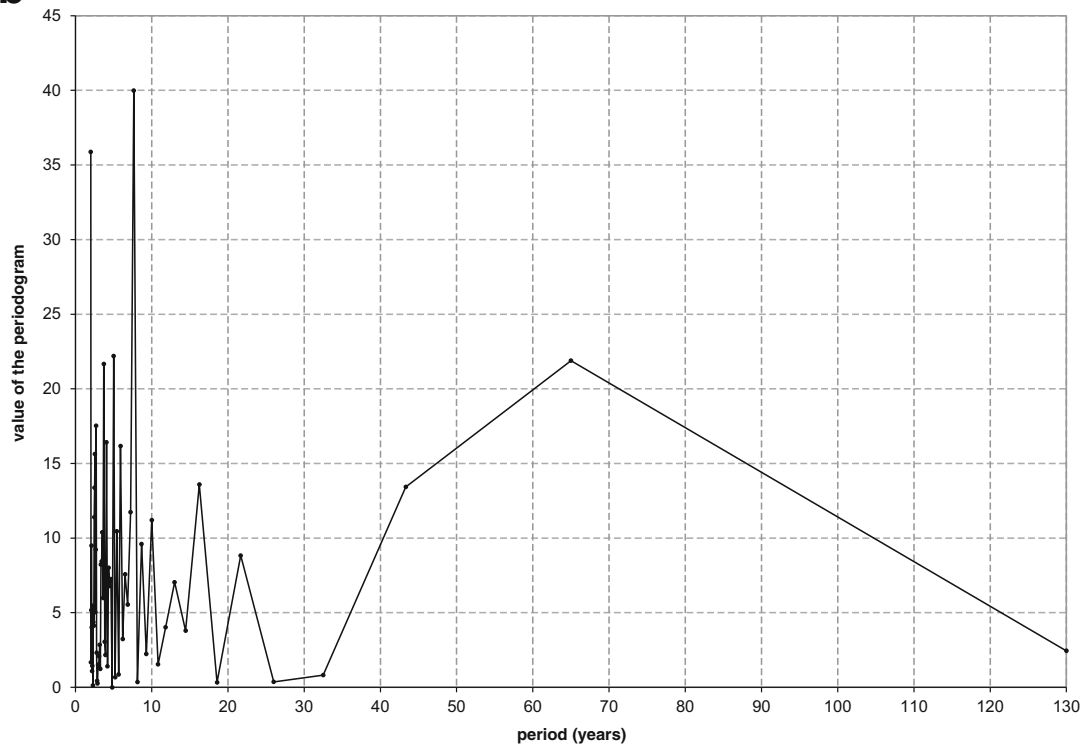


period, the average length of periods with $T>0{ }^{\circ} \mathrm{C}$ was 187 days, $\sigma=8$ ( 130 days in 1912 to 233 days in 2009). The length of the $T<0{ }^{\circ} \mathrm{C}$ period (thermal winter) was 178 on average, $\sigma=8$ (132 days in 2009 to 235 days in 1912). The progressing warming leads to shorter winters with a decreasing tendency of -16 days $/ 100$ years, earlier spring thaw and longer periods with above-zero temperatures (Fig. 3).

\subsection{Air temperature at Mt Śnieżka and mechanisms of atmospheric and oceanic circulation}

The attribute of climate in the Karkonosze mountains is relatively high interannual variability due to interactions between Icelandic Low and Azores High atmospheric pressure centres. The NAO index describes these relations (Fig. 4).

The area is directly influenced by the zonal circulation of maritime air masses from the North Atlantic, which is illustrated by a strong relation between thermal conditions at $\mathrm{Mt}$ Śnieżka and the NAO index. This relationship is evident in the level of mean annual air temperature. This is confirmed by a statistical test in which the cross-correlation coefficient $(\rho)$ is more than twice as high as its standard error value (SE) (Fig. 5). The relationship strongly depends on geographical location - the closer to the ocean, the higher correlation (Luterbacher et al. 1999; Marsz 1999). Much weaker correlations are observed in the area of the Carpathians and the Alps (Migała 2005).

Observed are 2-3 and 7-8-year cycles of air temperature fluctuations, which is indicated by the spectral analysis of $\mathrm{Mt}$ Śnieżka mean annual air temperatures. The analysis shows similar periodicity of the NAO index. Both analyses also reveal a long-term cycle of 65 years (Fig. 6).

The long-term cycle of 65 years, recognised in the periodicity of air temperature in the Karkonosze mountains, can be identified as the impact of AMO (Atlantic Multidecadal Oscillation, Fig. 7). AMO explains the periodicity of sea surface temperature (SST) connected with a mechanism of deep ocean thermohaline circulation (Schlesinger and Ramankutty 1994; Enfield et al. 2001).

\subsection{Relations between macrotypes of atmospheric circulation and air temperature}

The influence of pressure fields over Europe and the North Atlantic on air temperature in the Karkonosze mountains was evaluated on the basis of atmospheric circulation macrotypes (German: Großwetterlagen) according to the classification of Hess and Brezowsky $(1952,1977)$ and Werner and Gerstengarbe (2010). Among the 29 circulation types distinguished by Hess and Brezowsky (1952, 1977), only eight in half of the cases $(53.9 \%)$ determined meteorological conditions in Central Europe (Table 6).

The four of the eight most frequent air circulation macrotypes Hochdruckbrücke Mitteleuropa (BM), Trog Mitteleuropa (TRM), Trog Westeuropa (TRW) and also South-Western cyclonic (SWc) have shown a marked increase in their frequency in the last decades of the twentieth century. The anticyclonic type "HM" with a centre over Central Europe reveals a downward trend (Fig. 8). Although the frequency of the dominant circulation "Wc" has not changed, there has been a change in the share from summer to winter. Such a modification of air pressure patterns over Europe had an impact on the climate conditions that prevailed at the end of the twentieth century and in the following decade (Kysely and Huth 2006).

Changes in the frequency of macrotypes of atmospheric circulation caused not only warming throughout the year but higher frequency of dry springs and summers. On one hand, this resulted in earlier vegetation, but on the other, it caused a
Fig. 7 Long-term course of AMO index, annual air temperature $(T)$ at Mt Śnieżka and NAO index

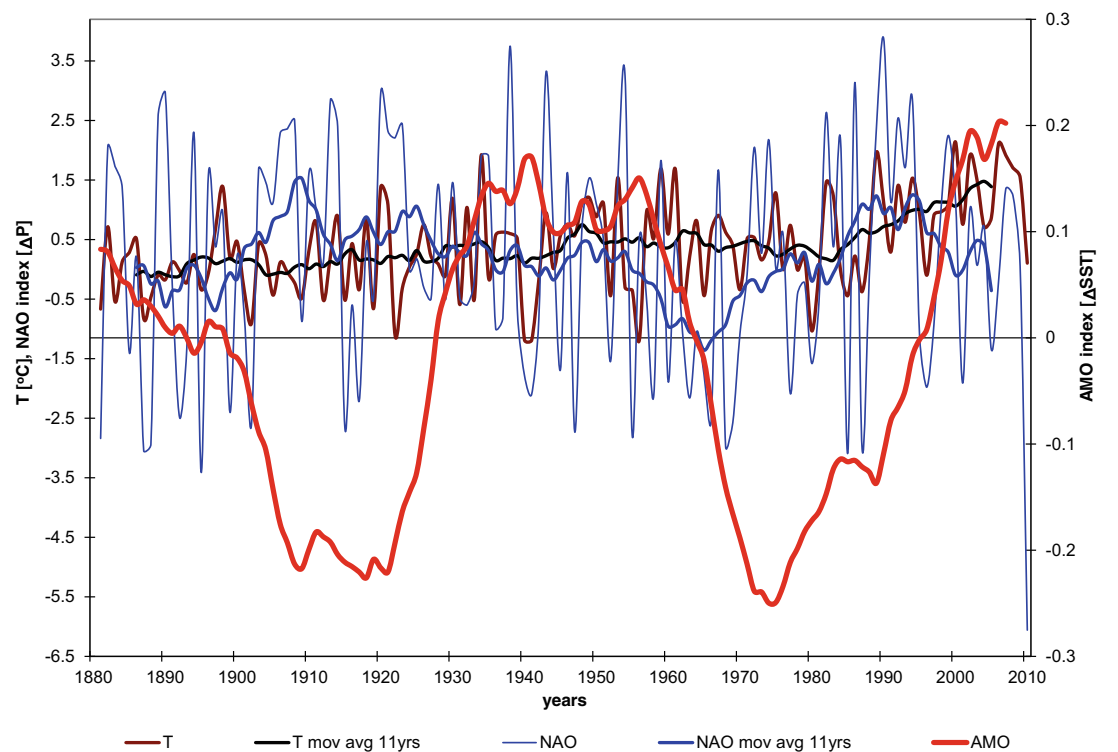


Table 6 Macrotypes of atmospheric circulation prevailing in 1881-2010

\begin{tabular}{rlr}
\hline Type & Description & $\begin{array}{c}\text { Share } \\
{[\%]}\end{array}$ \\
\hline Wc & Western cyclonic & 15.7 \\
HM & Anticyclonic with centre over Central Europe (Hoch Mitteleuropa) & 8.9 \\
BM & latitudinal anticyclonic ridge over Central Europe (Hochdruckbrücke Mitteleuropa) & 7.9 \\
Wa & Western anticyclonic & 5.8 \\
NWc & North-Western cyclonic & 4.8 \\
TRM & Cyclonic with meridional trough of low pressure over Central Europe (Trog Mitteleuropa) & 4.5 \\
TRW & Cyclonic with meridional trough of low pressure over Western Europe blocked by high- & 3.6 \\
& pressure systems located over Central Atlantic and Western Russia (Trog Westeuropa) & \\
SWc & South-Western cyclonic & 2.7 \\
& & Total \\
& & 53.9 \\
\hline
\end{tabular}

higher risk of drought in summer. Moreover, the reduced frequency of anticyclonic patterns in winter lowered the number of icing days, with an effect on the increase of mean air temperature in that season.

To describe the time dependence structure between the two time series, a cross-correlation function has been used. To decide whether the estimated correlations are statistically significant, their doubled standard errors $( \pm 2 \mathrm{SE})$ were estimated as the intervals, which limits the confidence level to 0.95 . This made it possible to indicate the types of atmospheric circulation whose relationship with air temperature at Mt Śnieżka determines the crosscorrelation coefficient $(\rho)$ which exceeds more than twice its standard error value. The evaluation results are shown in Figs. 9, 10, 11 and 12.

In the spring quarter (March-May), the type of atmospheric circulation (SWc and $\mathrm{BM}$ ) determined higher minimum temperatures, while the TRW type determined higher maximum temperature values (Fig. 9).

The SWc circulation type determined higher summer temperatures. The cross-correlation coefficient (@) in the statistical evaluation of both the maximum and minimum temperatures is above the standard error (SE) (Fig. 10).

Three circulation types (SWc, TRW $\left(T_{\max }, T_{\min }\right)$ and HM $\left.\left(T_{\max }\right)\right)$ determined the increased extreme temperatures in the autumn quarter. In the second half of the twentieth century, the last type (HM) was markedly less frequent (by more than a half) from 9.8 to $12.1 \%$ in the first half of the century to 4.9 $5.2 \%$ in $1971-2010$ (Fig. 11).

Thermal conditions of the winter season (XII-II) at Mt Śnieżka were clearly shaped by Western cyclonic (Wc type) and South-Western cyclonic (SWc) circulation (Fig. 12). Furthermore, the higher maximum temperatures were associated with anticyclonic circulation with a high centre in Central
Fig. 8 Average frequency of the selected macrotypes of atmospheric circulation in the decades of the period 1881-2010 according to Hess and Brezowsky classification

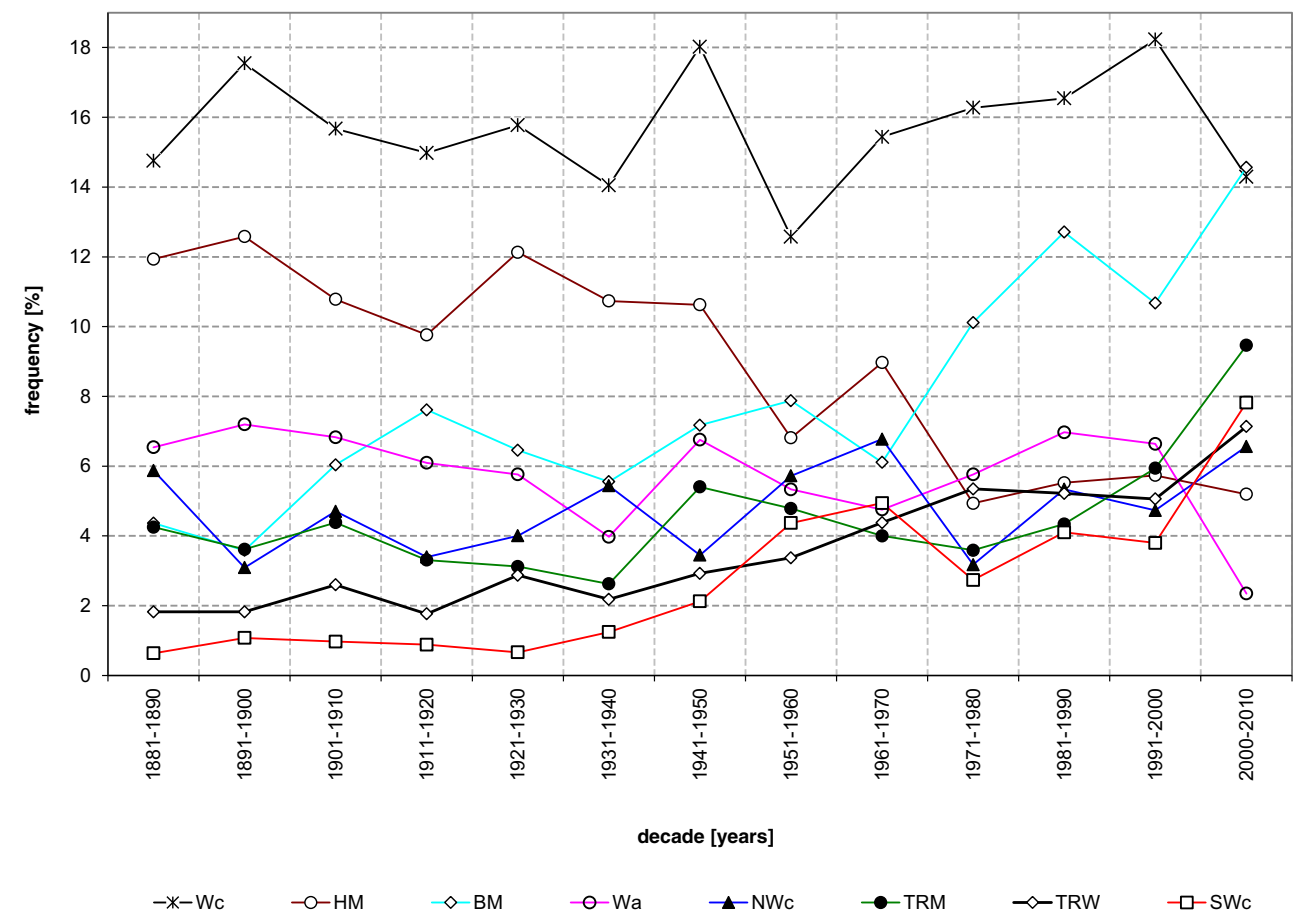


Fig. 9 Moving averages (5 yrs) of quarterly means of minimum and maximum air temperature at Mt Śnieżka and frequency of BM, SWc and TRW types of atmospheric circulation (a) and cross-correlation function (b) between temperature and circulation during spring seasons in the years 1881-2010 a
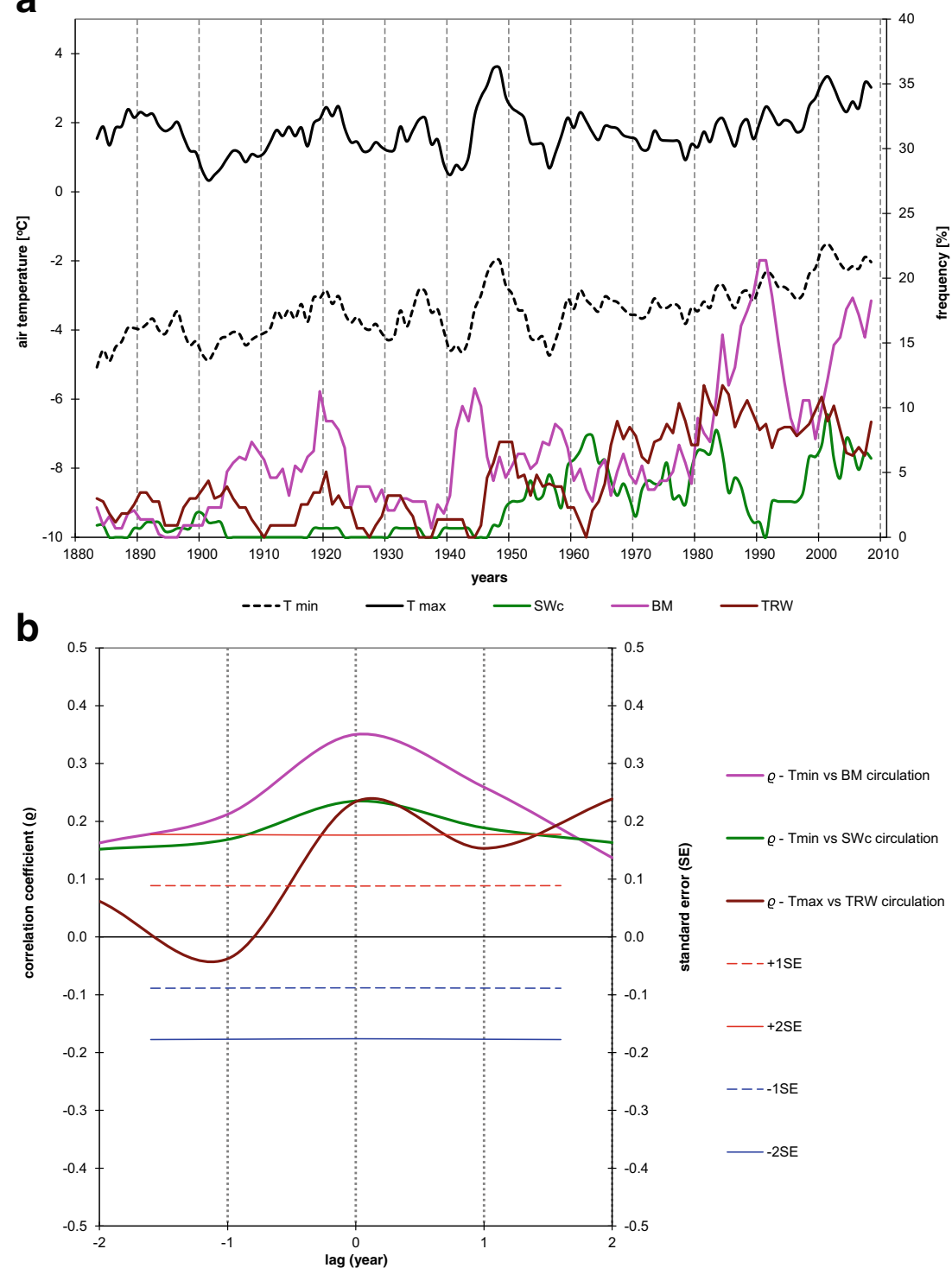

Europe (HM type); in such conditions, air settles in free atmosphere and temperature inversion occurs. For the winter season, the type had lower frequency from $12.6 \%$ in the first half of the twentieth century to $7.1 \%$ in 1971-2010; however, in respective seasons, the HM type contributed to higher temperatures in high mountain areas.

\section{Discussion}

The higher rate of minimum air temperature increase than for maximum temperature at Mt Śnieżka which led to reduced temperature amplitudes has been observed in a number of locations worldwide (Karl et al. 1993; Głowicki 2003). This tendency is yet to be accounted for in the literature. It may be associated with the intensified greenhouse effect in which greenhouse gases slow down the cooling of the ground which emits heat as infrared radiation. Therefore, night temperatures rise more quickly than day temperatures. If the global warming were caused by the sun only, a higher rate of warming during the day would be expected (Alexander et al. 2006).

The periodicity of 2-3 and 7-8 years detected both in the fluctuations of annual air temperature values in the Karkonosze mountains and in the NAO index changes could be directly associated with the rate of the El Niño Southern Oscillation (ENSO) mechanism. The comparable cycles suggest that ENSO force circulation (with a periodicity of 2-3 and 7-8 years) had an effect on the Hadley Cell responsible i.e. for the position and strength of the Azores High impacting weather in Europe. The concept was confirmed in the studies carried out by Quan et al. (2004), but according to Mitas and Clement (2005), the upward tendency of Hadley Cell strength cannot be attributed to increased ENSO frequency. 
Fig. 10 Moving averages (5 yrs) of quarterly means of minimum and maximum air temperature at Mt Śnieżka and frequency of SWc and BM types of atmospheric circulation (a) and cross-correlation function (b) between temperature and circulation during summer seasons in the years 1881-2010 a

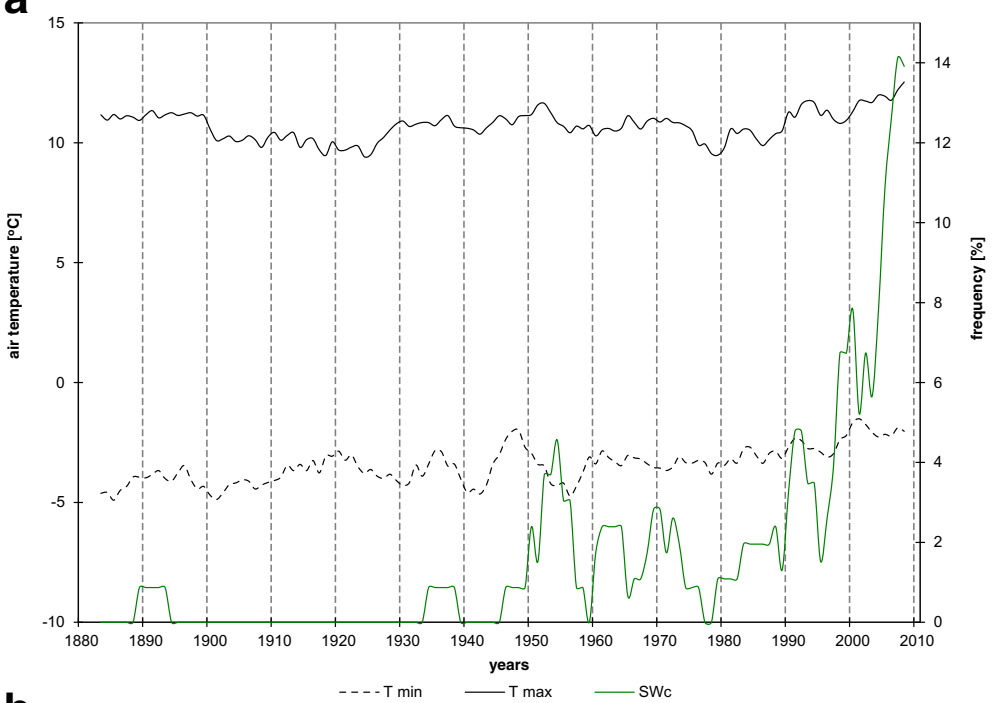

b

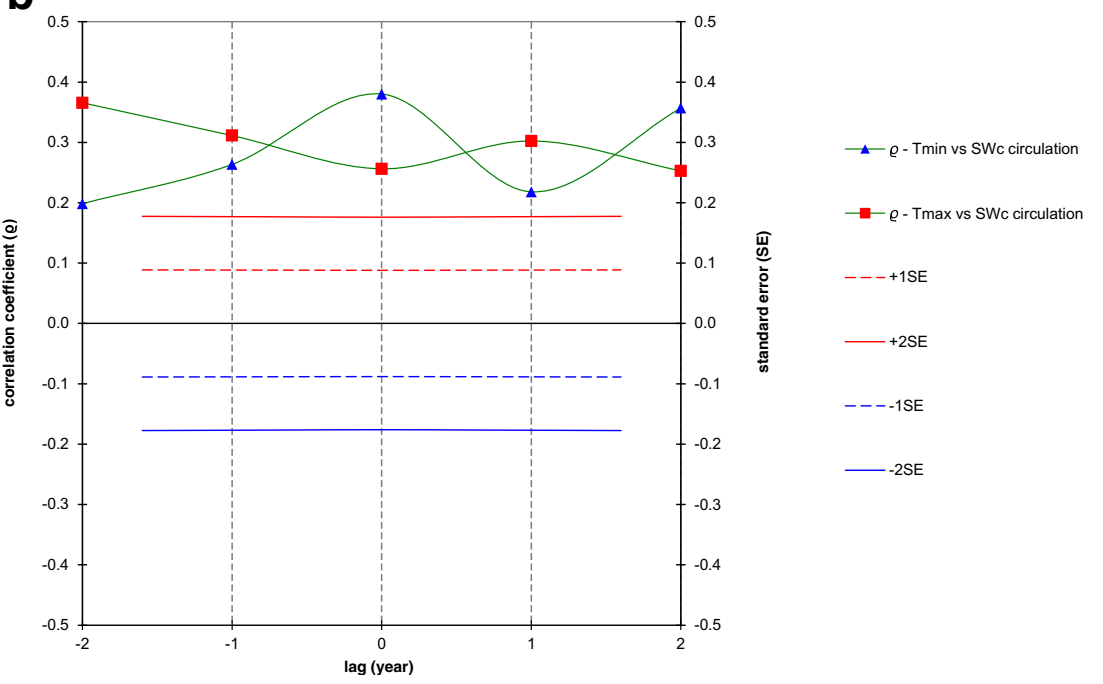

According to Urban and Tomczyński (2015), air temperatures at Mt Śnieżka were strongly correlated (correlation coefficient close to 1.0) with the average Wolf number for 22-year cycles of solar magnetic variability. The impact of solar activity and cosmic radiation on global climate is clear (Svensmark and Friis-Christensen 1997; Lockwood 2012; Harvey 2013). However, in the recent decades, air temperatures have markedly increased, while solar activity has fluctuated only with a downward trend (Lockwood 2008). However, for the 1989-2012 cycle, highly increased air temperatures were seen with lower average Wolf numbers at the same time. This suggests that no significant tendency occurred for total solar radiation, UV and cosmic radiation in the last 30 years; therefore, at least the last warming event must have a different origin (Usoskin et al. 2005). Scafetta and West (2006) note that as of 1975, the global warming accelerated much more than expected based on solar effects only. It is concluded, then, that higher temperatures for the 1989-2012 cycle of solar magnetic variability may reveal a synergy effect to which astrophysical effects and atmospheric and oceanic circulation effects contribute, modified by constantly increasing anthropogenic factors.

The open question is: at what scale and to what extent do the long-term data from the Karkonosze mountains and the data from the other mountain observatories confirm the range of human impact on climate?

\section{Conclusions}

Thermal conditions of the Karkonosze (Mt Śnieżka) accurately reflect the global climate trend and impact of multiscale mechanisms of atmospheric and oceanic circulation.

The mean annual temperature trend for 1881-2010 at Mt Śnieżka is $0.104{ }^{\circ} \mathrm{C} / 10$ years (Table 3). Higher temperatures are seen in successive decades, of which 2000-2010 was the warmest with a mean temperature of $1.5^{\circ} \mathrm{C}$. Since the early 
Fig. 11 Moving averages (5 yrs) of quarterly means of minimum and maximum air temperature at Mt Śnieżka and frequency of SWc, TRW and HM types of atmospheric circulation (a) and crosscorrelation function (b) between temperature and circulation during autumn seasons in the years 1881-2010

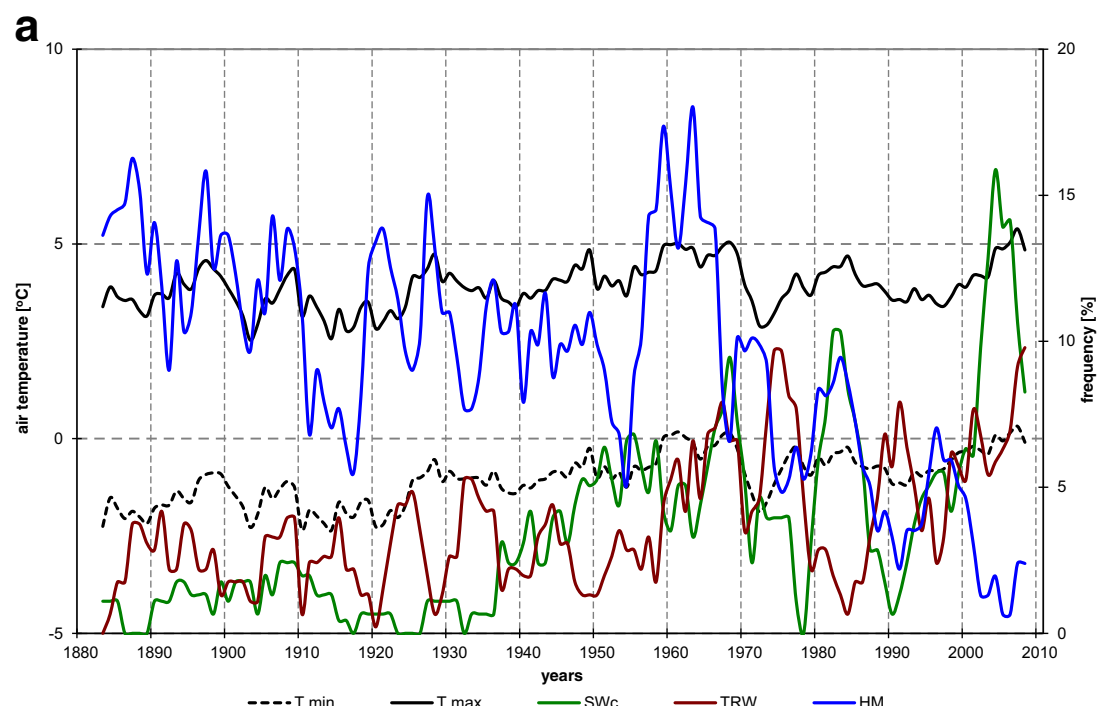

b

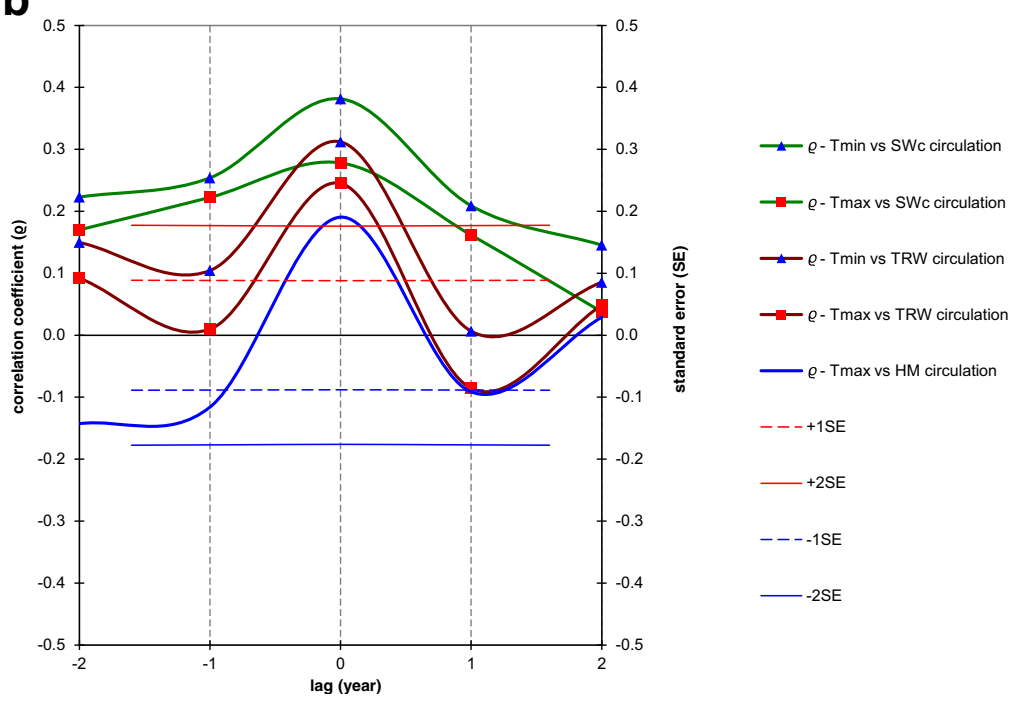

1990s, a marked increase in the frequency of very warm and warm months has been seen, with a reduced number of very cold and cold months. This is noticeable both with respect to average and extreme temperatures, and more significant for monthly $T_{\min }$ averages than for monthly $T_{\max }$ averages. This tendency is determined mainly by the strong increase in daily temperature minima $\left(+0.145^{\circ} \mathrm{C} / 10\right.$ years $)$, twice as high as for daily maxima $\left(+0.062{ }^{\circ} \mathrm{C} / 10\right.$ years $)$. As a result, a negative trend for average annual air temperature amplitudes is noted of $-0.083{ }^{\circ} \mathrm{C} / 10$ years, proving the higher impact of the Ocean and frequency of Atlantic air masses. However, the tendency for higher mean annual temperatures $\left(T_{\mathrm{avg}}\right)$ has been recently markedly lower with even a downward trend.

Detailed analysis indicates a complex nature of the relationship between the frequency of atmospheric circulation macrotypes and air temperature at Mt Śnieżka. While it demonstrates a direct relationship between the NAO index and the mean annual air temperature for 1881-2010, relationships at the annual level have not been identified for atmospheric circulation macrotypes. Such relations are found only for average temperature extremes $\left(T_{\max }, T_{\min }\right)$ in the quarterly seasons of spring, summer, autumn and winter.

The steady increase in air temperatures is affected by the changed frequency of circulation types and paths of air masses over the year. The area is directly influenced by the zonal circulation of maritime air masses from the North Atlantic, which is illustrated by a strong relation between thermal conditions at Mt Śnieżka and the NAO index. Observed are 2-3 and 7-8-year cycles of air temperature fluctuations, which is indicated by the spectral analysis of mean annual air temperatures at Mt Śnieżka. The analysis shows similar periodicity of the NAO index. Both analyses also reveal a long-term cycle of 65 years. The long-term cycle of 65 years, recognised in the periodicity of air temperature in the Karkonosze mountains, can be identified as the impact of AMO (Atlantic Multidecadal Oscillation). 
Fig. 12 Moving averages (5 yrs) of quarterly means of minimum and maximum air temperature at Mt Śnieżka and frequency of Wc, SWc and HM types of atmospheric circulation (a) and cross-correlation function (b) between temperature and circulation during winter seasons in the years 1881-2010
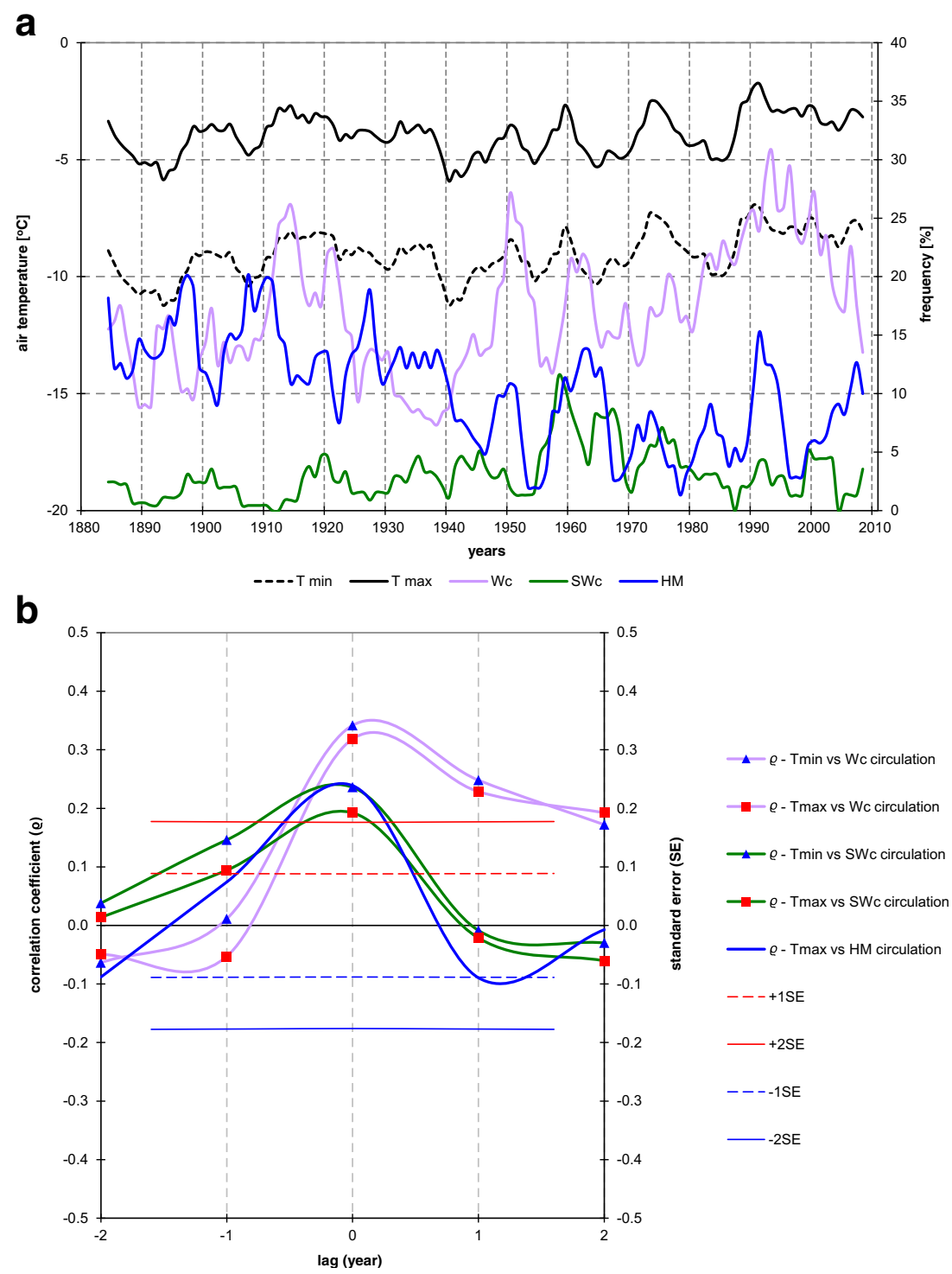

Four of the eight most frequent circulation types (BM, TRM, TRW and also SWc) had markedly higher frequencies in the last decades of the twentieth century. According to the Hess and Brezowsky classification (Werner and Gerstengarbe 2010) the pressure systems were the following: BM, with a latitudinal anticyclonic ridge over Central Europe; TRM, with a meridional trough of low pressure over Central Europe; TRW, with a meridional trough of low pressure over Western Europe blocked by high-pressure systems located over Central Atlantic and Western Russia; and SWc, South-Western cyclonic circulation. The general change in the frequency of atmospheric circulation types caused not only annual warming but also higher frequency of dry spring and summer periods. This leads to an earlier growing season but on the other hand to a risk of physiological droughts in summer. Furthermore, the frequency of anticyclonic systems in Central Europe in winter was lower, thus reducing the number of sub-zero days and increasing average winter temperatures.
In accordance with the results of Urban and Tomczyński (2015), it can be concluded that higher temperatures for the 1989-2012 cycle of solar magnetic variability may reveal a synergy effect to which astrophysical effects and atmospheric and oceanic circulation effects contribute, modified by constantly increasing anthropogenic factors.

Acknowledgments This study was supported by the research project no. N N305 036940 of the Polish State Committee for Scientific Research. Meteorological data from Mt Śnieżka were elaborated within the framework of research tasks of the Institute of Meteorology and Water Management (IMGW-PIB). Language editing was done by Piotr Paryzek.

Open Access This article is distributed under the terms of the Creative Commons Attribution 4.0 International License (http:// creativecommons.org/licenses/by/4.0/), which permits unrestricted use, distribution, and reproduction in any medium, provided you give appropriate credit to the original author(s) and the source, provide a link to the Creative Commons license, and indicate if changes were made. 


\section{References}

Alexander LV, Zhang X, Peterson TC, Ceasar J, Gleason B, Tank AM, Haylock M, Collins D, Trewin B, Rahimzadeh F, Tagipour A, Kumar KR, Revadekar J, Griffiths G, Vincent L, Stephenson DB, Burn J, Aguilar E, Brunet M, Taylor M, New M, Zhai P, Rusticucci M, Vazquez-Aguirre JL (2006) Global observed changes in daily climate extremes of temperature and precipitation. J Geophys Res 111, D05109. doi:10.1029/2005JD006290

Auer I, Böhm R, Schöner W (2001) Austrian long-term climate 17672000. Multiple instrumental climate time series from Central Europe. Österreichische Beiträge zu Meteorologie und Geophysik, 25. Zentralanstalt für Meteorologie und Geodynamik, Wien Publ.Nr. 395, ISSN 1016-6254: 147 pp. http://www.zamg.ac.at/ histalp/download/abstract/Auer-etal-2001b-F.pdf. Accessed 25 Oct 2014

Bryś K, Bryś T (2010) Reconstruction of the 217-year (1791-2007) Wrocław air temperature and precipitation series. Bulletin of Geography_Physical Geography Series 3, Nicolaus Copernicus University, Poland: 121-171

Conrad V, Pollak LW (1950) Methods in climatology. Harvard University Press, Cambridge

Dubicka M, Głowicki B (2000a) Air temperature and cloudiness at Śnieżka between 1901 and 1998. Prace Inst Geogr UJ 107:205-212

Dubicka M, Głowicki B (2000b) Ekoklimat Karkonoszy w przekroju wieloletnim w świetle wskaźników kompleksowych. Opera Corcontica 37:55-61

Ellenberg H (1978) Vegetation Mitteleuropas mit den Alpen. E. Ulmer, Stuttgart

Enfield DB, Mestas-Nunez AM, Trimble PJ (2001) The Atlantic Multidecadal Oscillation and its relationship to rainfall and river flows in the continental U.S. Geophys Res Lett 28:2077-2080

Głowicki B (1998) Wieloletnia seria pomiarów temperatury powietrza na Śnieżce. In: Geoekologiczne Problemy Karkonoszy 1, Acarus. Poznań: 117-123

Głowicki B (2000) 20th-century variability to daily maxima and minima of air temperature in the Sudetic Mountains. Geographia Polonica 73(2):111-116

Głowicki B (2003) Symptoms of contemporary warming in the 100-year series of temperature measurements on the Śnieżka Mountains. Acta Univ Wratisl Studia Geogr 75(25):142-150

Głowicki B (2005) Klimat Karkonoszy. In: Mierzejewski M (ed) Karkonosze. Przyroda nieożywiona i człowiek. Wyd. Uniwersytetu Wrocławskiego, Poland, pp 381-397

Harvey JW (2013) The Sun in time. Space Sci Rev 176(1-4):47-58. doi: 10.1007/s11214-010-9726-z

Hess M (1968) Piętra klimatyczne w Alpach Wschodnich, Karpatach Zachodnich i w Sudetach. Przeglad Geograficzny 40(2):467-472

Hess P, Brezowsky H (1952) Katalog der Großwetterlagen Europas. Berichte des Deutschen Wetterdienstes 33, Berlin

Hess P, Brezowsky H (1977) Katalog der Großwetterlagen Europas 1881-1976, 3rd edn. Berichte des Deutschen Wetterdienstes 113, Berlin, Germany

Hurrell JW (1995) Decadal trends in the North Atlantic Oscillation: regional temperatures and precipitation. Science 269:676-679. doi:10. 1126/science.269.5224.676\# blank

Hurrell JW \& National Center for A tmospheric Research Staff (eds). Last modified 08 Oct 2013. The climate data guide: Hurrell North Atlantic Oscillation (NAO) index (station-based). https:// climatedataguide.ucar.edu/climate-data/hurrell-north-atlanticoscillation-nao-index-station-based. Accessed 22 Dec 2013

IPCC (2013) 5th Assessment Report Climate Change 2013. The Physical Science Basis. http://www.ipcc.ch. Accessed 30 January 2014

Jurkovic A, Majstorovic Z, Bohm R, Auer I, Gruber C, Hodzic S, Orlik A, Zulum D (2011) The Mountain Observatory Bjelasnica — history, analysis, homogenization and interpretation of a more than 100 years long temperature data set. Meteorologische Zeitschrift 20(3):291303

Kaplan SST V2 (2013) Data provided by the NOAA/OAR/ESRL PSD, Boulder, Colorado, USA, at http://www.esrl.noaa.gov/psd/. Accessed 30 January 2014

Karl TR, Knight RW, Gallo KP, Peterson TC, Jones PD, Kukla G, Plummer N, Razuvayev VN, Lindesay J, Charlson RJ (1993) A new perspective on recent global warming: asymmetric trends of daily maximum and minimum temperature. Bulletin of the American Meteorological Society 74(6):1007-1023. doi:10.1175/ 1520-0477(1993)074\%3C1007:anporg\%3E2.0.co;2

Kysely J, Huth R (2006) Changes in atmospheric circulation over Europe detected by objective and subjective methods. Theor Appl Climatol 85:19-36

Lockwood M (2008) Recent changes in solar outputs and the global mean surface temperature. III. Analysis of contributions to global mean air surface temperature rise. Proc R Soc A 464:1387-1404. doi:10. 1098/rspa.2007.0348

Lockwood M (2012) Solar influence on global and regional climates. Surv Geophys 33:503-534. doi:10.1007/s10712-012-9181-3

Lorenc H (2000) Studia nad 220-letnią (1779-1998) temperatury powietrza w Warszawie oraz ocena jej wiekowych tendencji. Materiały Badawcze, seria Meteorologia, 31, IMGW Warszawa: 59-86

Lorenc H, Suwalska-Bogucka M (1995) Metody obliczania średniej dobowej temperatury i wilgotności względnej powietrza. Materiały Badawcze, seria Meteorologia, 24, IMGW Warszawa: 5-41

Luterbacher I, Schmutz C, Gyalistras D, Eleni Xoplaki E, Wanner H (1999) Reconstruction of monthly NAO and EU indices back to AD 1675. Geophys Res Lett 26(17):2745-2748

Marsz A (1999) Rozmiary wpływu Oscylacji Południowej na niektóre cechy klimatu rejonu południowego wybrzeża Bałtyku. Przegląd Geofizyczny 44(1-2):53-59

Migała K (2005) Piętra klimatyczne w górach Europy a problem zmian globalnych. Acta Univ Wratisl, 2718, Studia Geograficzne 78, Wyd. Uni. Wroc., Wrocław

Migała K, Czerwiński J (2004) Das Observatorium auf der Schneekoppe (Śnieżka) im Riesengebirge (Karkonosze) 1603 m, westliche Sudeten, Polen, 100.Hahresbericht des Sonnblick - Vereines für das Jahr 2002, Wien: 24-28

Mitas CM, Clement A (2005) Has the Hadley cell been strengthening in recent decades? Geophys Res Lett 32, L03809. doi:10.1029/ 2004GL021765

Obrębska-Starklowa B, Bednarz Z, Niedźwiedź T, Trepińska J (1994) Klimat Karpat w okresie globalnego ocieplenia i prognozowane zmiany gospodarcze. Problemy Zagospodarowania Ziem Górskich 37:13-38

Pyka JL (1998) Temperatura powietrza we Wrocławiu w latach 18811995 2022. Acta Univ Wratisl Prace Inst Geogr Seria C Met i Klimat 5(2022):25-40

Quan XW, Diaz HF, Hoerling MP et al (2004) Change in the tropical Hadley cell since 1950. In: Diaz HF (ed) The Hadley circulation: past, present, and future. Kluwer, Dordrecht, pp 85-120

Scafetta N, West BJ (2006) Phenomenological solar signature in 400 years of reconstructed Northern Hemisphere temperature record. http://www.acrim.com/Reference\%20Files/Sun\%20\&\%20Global $\%$ 20Warming GRL 2006.pdf. Accessed 16 Nov 2014

Schlesinger ME, Ramankutty N (1994) An oscillation in the global climate system of period 65-70 years. Nature 367(6465):723-726

Schönwiese CD, Rapp J (1997) Climate trend atlas of Europe based on observations 1891-1990. Kluwer, Dordrecht. doi:10.1007/978-94015-8818-8

Sobik M, Błaś M, Migała M, Godek M, Nasiółkowski T (2013) Klimat. In: Knapik R, Raj A (eds) Przyroda Karkonoskiego Parku Narodowego. Karkonoski Park Narodowy, Jelenia Góra, DIMOGRAF Bielsko-Biała, pp 147-186 
Svensmark H, Friis-Christensen E (1997) Variation of cosmic ray flux and global cloud coverage - a missing link in solar-climate relationships. Journal of Atmospheric and Solar-Terrestrial Physics 59(11): 1225-1232. doi:10.1016/s1364-6826(97)00001-1

Trepińska J, Kowanetz L (1997) Wieloletni przebieg średnich miesięcznych wartości temperatury powietrza w Krakowie (17921995). In: Trepińska J (ed) Wahania klimatu w Krakowie (17921995). Inst. Geogr. UJ, Kraków, pp 99-130

Urban G (2010) Ocena wybranych metod obliczania średniej dobowej, miesięcznej i rocznej wartości temperatury powietrza (na przykładzie Sudetów Zachodnich i ich przedpola). Opera Corcontica 47:23-34

Urban G (2013) Evaluation of accuracy of selected methods of calculation of the daily mean air temperature depending on atmospheric circulation (the case study of the Western Sudety Mountains and their foreland). Opera Corcontica 50:107-122
Urban G, Tomczyński K (2015) Air temperature trends atMount Śnieżka (in Sudetes Mts in Poland) and solar variation in 1881-2012. Acta Geogr Slov 57, doi:10.3986/AGS.837, in press

Usoskin IG, Schüssler M, Solanki P, Mursula K (2005) Solar activity over the last 1150 years: does it correlate with climate? In: Favata F, Hussain GAJ, Battrick B (ed) Proc The 13th Cambridge Workshop on Cool Stars, Stellar Systems and the Sun. ESA SP560, Noordwijk: 19-22

Werner PC, Gerstengarbe FW (2010) Katalog der Grosswetterlagen Europas (1881-2009) nach Paul Hess und Helmut Brezowsky, 7th edn. PIK Report 119. Potsdam, Germany. https://www.pik-potsdam. de/research/publications/pikreports/.files/pr119.pdf. Accessed 30 Jan 2014

Wibig J, Głowicki B (2002) Trends of minimum and maximum temperature in Poland. Climate Research 20(2):122-133. doi:10.3354/ cr020123 